\title{
EUROPEAN UNION REFORMS DIMINISH THE ROLE OF THE TURKISH MILITARY: ANKARA KNOCKING ON BRUSSELS' DOOR*
}

\author{
SONER ÇAĞAPTAY
}

On August 8, 2003, the seventh European Union (EU) reform package went into effect in Turkey, significantly curbing the role of the military in politics. This legislation, passed by the Justice and Development Party (AKP) government on August 4, follows six previous packages adopted since February 2002. Collectively, these reform measures have vastly liberalized the country's political system, facilitating Kurdish broadcasting and education, abolishing the death penalty, and subjecting Turkish courts to the European Court of Human Rights. Turkey now has laws guaranteeing freedom of speech, and the military is no longer the kingmaker in Ankara. As a result, AKP-a self-styled "conservative democratic" party with an identifiable "Islamist pedigree"-anticipates that Turkey will pass muster when Brussels reviews its candidacy for EU membership in June 2004. Ankara hopes that the EU will establish an accession calendar, opening the way for Turkey's eventual entry into the union, perhaps within the next decade. These developments are crucial to

\footnotetext{
*This paper was first issued by The Washington Institute for Near East Policy, No.
} 781 on August 12, 2003. 
Turkey's future. Which path will the country take now that the military is stripped of its role as a decisionmaking body? Will the EU open its doors to Turkey?

\section{The Changing Role of the Turkish Military.}

The seventh package eliminates the structural means with which the Turkish military has influenced the political system in the past. New reform measures include:

- Limiting the executive powers and areas of responsibility of the National Security Council (NSC). Previously, the NSC was headed by the military and had sole responsibility for drafting Turkey's national security and foreign policy doctrines and passing them to the government for implementation. Now, the NSC is to become an advisory board.

- Increasing the civilian presence on the NSC. The post of NSC secretary-general, hitherto filled by an army general, can now be held by a civilian, to be appointed by the president from a list of candidates selected by the prime minister.

- Subjecting the NSC to executive authority. Previously, the NSC met monthly and communicated policy to the cabinet, thereby setting the political tempo for Ankara. Now, the NSC is to convene only every other month and report to the deputy prime minister.

The seventh package also brings military expenditures, which were not publicly audited in the past, under the scrutiny of the Court of Accounts-a Turkish body similar to the U.S. General Accounting Office.

\section{What Do the Reforms Mean for Turkey?}

The main reason why the seventh package passed through the Turkish parliament rather smoothly - with the public offering strong support and the military voicing only a few quiet reservations - is that 
democratization has become a political avalanche in the country, driven by many powerful catalysts, including the prospect of EU accession. There is wide consensus among Turks that political liberalization toward EU membership can only be good. Hence, those who are unhappy with the reforms nevertheless find it difficult to resist liberalization, since they do not want to be in the highly unpopular position of being culpable for impeding EU accession.

AKP views the reforms as part of a process in which Turkey moves closer to the EU while the military's role as a checks-andbalance institution is altered. Currently, AKP holds 366 seats in the Turkish parliament, only one short of the two-thirds majority needed to make constitutional amendments. Over the coming days, two to four additional members of parliament may join the party, giving it a mandate to pass whatever legislation it wishes. (The president can veto legislation passed by the parliament; however, if the parliament resubmits the legislation, the president must either approve it or open it to a referendum.) Now that the military's executive role is diminished, how will AKP behave once it has a parliamentary majority? So far, the party has compromised with the military. For example, despite the new rule permitting civilians to serve as NCS secretary-general, AKP recently deliberated with the army and agreed to appoint a general as NSC head for a "transitionary period of one year."

\section{What Can the EU Do Now?}

The EU decides on accession of new members using the socalled "Copenhagen Criteria," which it created in 1993:

- The political criterion ("the stability of institutions guaranteeing democracy, the rule of law, human rights, and the respect and protection of minorities");

- The economic criterion ("the existence of a functioning market economy");

- The Acquis Communautaire ("the ability to take on the obligations of membership"). 
Only countries that conform to these criteria are granted accession calendars. Brussels has long told Turkey-a market economy in customs union with the EU since 1995-that it does not qualify for EU membership because it has not satisfied the political criterion. Specifically, the EU has argued that Turkey's "treatment of Kurds was poor" and that its military "wielded too much influence." The latest reforms have brought Turkey closer to satisfying the EU's expectations. Whether or not the EU discerns this progress will become apparent in October, when Brussels will issue a progress report ahead of its June 2004 decision regarding Turkish accession.

If the EU looks for glitches in Turkey's implementation of the Copenhagen Criteria, it will surely find them. Yet, Brussels should keep in mind that even current EU member states do not implement these criteria uniformly. For instance, EU countries have varying policies on broadcast rights in non-national languages - one of the likely yardsticks for measuring Turkey's implementation of the political criterion. According to the European Bureau of Lesser Used Languages - an independent body that receives EU funds-the Basque language is broadcast on French television "only one to two minutes daily," while Catalan appears "about 10 minutes once a fortnight." Greece provides no broadcasting in Macedonian or Bulgarian, and only "occasional broadcasting of Vlach [language] songs on local radios." Therefore, Brussels should evaluate Ankara's efforts to implement the Copenhagen Criteria (e.g., its decisions regarding Kurdish broadcasting) based on Turkish modalities. What matters is that Turkey respects the spirit of the criteria, as indicated by its most recent reforms. Brussels should also note that the reforms have effectively made EU accession the new fail-safe of Turkish democracy.

\section{Significance for the United States.}

From the U.S. perspective, there are two ways of viewing the reform process in Turkey. The first view holds that Washington should stand behind AKP and the reforms, in the hope that the party's success will prove that Turkey is a democracy and that democracy and Islam are compatible. The second view holds that an Islamoriented party coming to power is not a prerequisite for a Muslim country to prove that it is democratic; rather, a Muslim country 
should be regarded as a democracy if and when it has democratic parties taking office through competitive, unrigged elections. Turkey, whose elections have been free and fair since 1950, is a democracyperhaps an illiberal one at times, but still a staunch and functioning democracy. The United States should applaud that record, stand behind Ankara's political reforms, and support democratic consolidation in Turkey regardless of who is responsible for it. 